\title{
Endocranial anatomy of the ceratopsid dinosaur Triceratops and interpretations of sensory and motor function
}

\author{
Rina Sakagami ${ }^{\text {Corresp., } 1}$, Soichiro Kawabe ${ }^{2,3}$ \\ ${ }^{1}$ Department of Bioscience, Fukui Prefectural University, Yoshida-gun, Eiheijicho, Fukui, Japan \\ 2 Institute of Dinosaur Research, Fukui Prefectural University, Yoshida-gun, Eiheijicho, Fukui, Japan \\ 3 Fukui Prefectural Dinosaur Museum, Katsuyama, Fukui, Japan \\ Corresponding Author: Rina Sakagami \\ Email address: sakagami.rina@gmail.com
}

Triceratops is one of the well-known Cretaceous ceratopsian dinosaurs. The ecology of Triceratops has been controversial because of its unique morphological features. However, arguments based on brain and inner ear structures have been scarce. In this study, two braincases (FPDM-V-9677 and FPDM-V-9775) were analyzed with computed tomography to generate three-dimensional virtual renderings of the endocasts of the cranial cavities and bony labyrinths. Quantitative analysis, including comparison of linear measurements of the degree of development of the olfactory bulb and inner ear, was performed on these virtual endocasts to acquire detailed neuroanatomical information. When compared with other dinosaurs, the olfactory bulb of Triceratops is relatively small, indicating that Triceratops had a reduced acuity in sense of smell. The lateral semicircular canal reveals that the basicranial axis of Triceratops is approximately $45^{\circ}$ to the ground, which is an effective angle to display their horns as well as frill, and to graze. The semicircular canals of Triceratops are relatively smaller than those of primitive ceratopsians, such as Psittacosaurus and Protoceratops, suggesting that sensory input for the reflexive stabilization of gaze and posture of Triceratops was less developed than that of primitive ceratopsians. The cochlear length of Triceratops is relatively short when compared with other dinosaurs. Because cochlear length correlates with hearing frequency, Triceratops was likely adapted to hearing low frequencies. 


\title{
1 Endocranial anatomy of the ceratopsid dinosaur
}

\section{Triceratops and interpretations of sensory and motor}

\section{3 function}

4

Rina Sakagami ${ }^{1}$ and Soichiro Kawabe ${ }^{2,3}$

\author{
${ }^{1}$ Department of Bioscience, Fukui Prefectural University, Matsuokakenjojima 4-1-1, Yoshida- \\ gun, Eiheijicho, Fukui, Japan \\ ${ }^{2}$ Institute of Dinosaur Research, Fukui Prefectural University, Matsuokakenjojima 4-1-1, \\ Yoshida-gun, Eiheijicho, Fukui, Japan \\ ${ }^{3}$ Fukui Prefectural Dinosaur Museum, Terao 51-11, Muroko, Katsuyama, Fukui, Japan \\ Corresponding Author: \\ Rina Sakagami ${ }^{1}$ \\ Matsuokakenjojima 4-1-1, Yoshida-gun, Eiheijicho, Fukui, 910-1195, Japan \\ Email address: sakagami.rina@gmail.com
}

\section{Abstract}

Triceratops is one of the well-known Cretaceous ceratopsian dinosaurs. The ecology of Triceratops has been controversial because of its unique morphological features. However, arguments based on brain and inner ear structures have been scarce. In this study, two braincases (FPDM-V-9677 and FPDM-V-9775) were analyzed with computed tomography to generate three-dimensional virtual renderings of the endocasts of the cranial cavities and bony labyrinths. Quantitative analysis, including comparison of linear measurements of the degree of development of the olfactory bulb and inner ear, was performed on these virtual endocasts to acquire detailed neuroanatomical information. When compared with other dinosaurs, the olfactory bulb of Triceratops is relatively small, indicating that Triceratops had a reduced acuity in sense of smell. The lateral semicircular canal reveals that the basicranial axis of Triceratops is approximately $45^{\circ}$ to the ground, which is an effective angle to display their horns as well as frill, and to graze. The semicircular canals of Triceratops are relatively smaller than those of primitive ceratopsians, such as Psittacosaurus and Protoceratops, suggesting that sensory input for the reflexive stabilization of gaze and posture of Triceratops was less developed than that of 
36

37

38

39

40

41

42

43

44

45

46

47

48

49

50

51

52

53

54

55

56

57

58

59

60

61

62

63

64

65

66

67

68

69

70

71

72

73

74

75

primitive ceratopsians. The cochlear length of Triceratops is relatively short when compared with other dinosaurs. Because cochlear length correlates with hearing frequency, Triceratops was likely adapted to hearing low frequencies.

\section{Introduction}

A number of research works have discussed the sensorineural function of some ceratopsians based on neuroanatomical characteristics (Brown, 1914; Brown \& Schlaikjer, 1940; Hopson, 1979; Forster, 1996; Zhou et al., 2007; Witmer \& Ridgely, 2008). In particular, computed tomography (CT) has been used to capture such characteristics more accurately. For example, previous studies analyzed the skulls of Psittacosaurus using CT and reconstructed their virtual cranial endocast (Zhou et al., 2007; Bullar et al., 2019; Napoli et al., 2019). They observed various sensorineural anatomical features of Psittacosaurus on the basis of virtual endocasts. Bullar et al. (2019) compared the inner ear morphology of three specimens of $P$. lujiatunensis and discussed that their head posture changes with growth. Napoli et al. (2019) described the brain endocast and endosseous labyrinth of $P$. amitabha. Zhou et al. (2007) found that Psittacosaurus had tall vertical semicircular canals, which are larger than those of Protoceratops and Ceratopsidae. Because large curvature of the canals is consistent with, and indicative of, the ability to stabilize the gaze or locomotion maneuverability in some mammals and archosaurs, including birds (Turkewitsch, 1932; Spoor \& Zonneveld, 1998; Spoor et al., 2002; Witmer et al., 2003; Spoor et al., 2007), it was inferred that Psittacosaurus was more agile than neoceratopsians. Additionally, Zhou et al. (2007) described Psittacosaurus as having a relatively short cochlear duct and suggested that hearing in Psittacosaurus was limited to lower frequencies. They estimated further that Psittacosaurus had large olfactory bulbs and argued that they had an acute sense of smell.

The endocranial structures of a basal neoceratopsian have also been elucidated in recent years, in which Zhang et al. (2019) illustrated the endocranial structures of Auroraceratops. The olfactory bulbs of Auroraceratops are larger than that of more derived ceratopsian Pachyrhinosaurus but is similar to that of Pachyrhinosaurus in that it is laterally wide and flat. They concluded that Auroraceratops had a keener sense of smell than Pachyrhinosaurus. They also found that the semicircular canals of Auroraceratops are slender and curved, being similar to that of Psittacosaurus. However, it differs from those of more derived neoceratopsians such as Pachyrhinosaurus and Anchiceratops with thick and short canals. Although they have made such morphological comparisons, they have not discussed the ecology of basal neoceratopsians based on inner ear morphology.

For the centrosaurine Pachyrhinosaurus, the brain endocasts of $P$. canadensis (Langston, 1975), P. lakustai (Witmer \& Ridgely, 2008) and P. perotorum (Tykoski \& Fiorillo, 2012) have been described. Witmer and Ridgely (2008) described a virtual endocast of $P$. lakustai and discussed their paleoecology. Specifically, they found that Pachyrhinosaurus possesses more elongate semicircular canals than some other neoceratopsians. Elongation of semicircular canals 
76

77

78

79

80

81

82

83

84

85

86

87

88

89

90

91

92

93

94

95

96

97

98

99

100

101

102

103

104

105

106

107

108

109

110

111

112

113

114

115

is linked to coordinating eye movements and head rotation (Spoor et al., 2007). The authors considered that this elongation may have aided this species to gaze more steadily in comparison to some other neoceratopsians (Witmer \& Ridgely, 2008). In addition, Pachyrhinosaurus has a short cochlear duct, suggesting that exceptional hearing sense was not important for Pachyrhinosaurus. Witmer and Ridgely (2008) also described the small olfactory bulbs, cerebrum, optic tecta, and cerebellum in Pachyrhinosaurus, concluding that the smallness of these regions of the brain may suggest that precise sensory integration and control were of lesser importance for Pachyrhinosaurus.

The natural endocast of Anchiceratops has been reported as an example within chasmosaurines (Brown, 1914). Later, Zhou et al. (2007) mentioned that the anterior semicircular canals (ASC) seen in Anchiceratops could be considered broadly similar to the posterior semicircular canal (PSC) in curvature and dimensions. A previous study reported that in humans and birds, more agile or high-degree maneuverable species have larger semicircular canals than that of slow-moving species (Spoor \& Zonneveld, 1998). From this view, Anchiceratops was considered less agile than Psittacosaurus.

These previous studies assessed the sensorineural attributes and endocranial capabilities of ceratopsians, but none conducted quantitative evaluations. Moreover, although natural endocasts, latex or plaster casts of the cranial cavity of Triceratops have also been described by some authors (Bürckhardt, 1892; Marsh, 1896; Hay, 1909; Gilmore, 1919; Forster, 1996; Erickson, 2017), detailed examination of the sensorineural function of Triceratops based on virtual endocasts has never been undertaken. Quantitative comparison of endocasts, including those of Triceratops, is essential to acquire information of neurological adaptation of ceratopsid dinosaurs. In this study, we obtained the CT scans of the braincases of Triceratops and made a quantitative comparison of the endocranial endocasts of them and other ceratopsians.

\section{Materials \& Methods}

\section{Specimens and CT scanning}

The braincases of Triceratops (FPDM-V-9677 and FPDM-V-9775) were scanned using a micro-focus X-ray CT XT H 450 (Nikon) at Nikon Instech High-Resolution X-ray CT Facility, Nikon Instech Yokohama Plant, Kanagawa, Japan. These specimens are stored at Fukui Prefectural Dinosaur Museum (FPDM), Fukui, Japan. They were collected from the Hell Creek Formation (Upper Cretaceous), Ziebach, South Dakota for FPDM-V-9677, and Marmarth, North Dakota for FPDM-V-9775, U.S.A. FPDM-V-9677 consists not only of braincase but also of nasal, premaxillae, maxillae, rostrum, postorbital, jugal, quadrate, parietal, and squamosal (Figs. $\mathrm{S} 1, \mathrm{~S} 2)$. On the other hand, FPDM-V-9775 is an isolated braincase lacking other skull elements (Fig. S2). For FPDM-V-9677, CT images were acquired under a voltage of $445 \mathrm{kV}$, current of $460 \mu \mathrm{A}$, interslice spacing of $0.25 \mathrm{~mm}$ and image size of $1,947 \times 1,998$ pixels. For FPDM-V9755, CT images were acquired under a voltage of $445 \mathrm{kV}$, current of $570 \mu \mathrm{A}$, interslice spacing of $0.25 \mathrm{~mm}$ and image size of $889 \times 1,267$ pixels. These parameters resulted in a voxel size of 
$1160.25 \mathrm{~mm}$ along the $\mathrm{z}$-axis and $0.20-0.25 \mathrm{~mm}$ in the $\mathrm{x}-$ and $\mathrm{y}$-axes. The CT images revealed that 117 FPDM-V-9775 is undeformed while its basicranial portion is missing.

118 We subsequently prepared the virtual endocasts of the cranial cavities and bony labyrinths 119 from the acquired CT images using Amira (v 2019.3, Mercury Computer Systems, San Diego, 120 CA, USA) (Figs. 1-3). Details of the methods used to prepare and examine the endocast models 121 are provided by Corfield et al. (2008). As is generally, the brain of reptiles, including most 122 dinosaurs, does not fill the endocranium (Jerison 1973; Hopson 1979). Thus, endocasts do not 123 provide complete information about brain morphology. Particularly the posterior part of the 124 endocast tends to be larger than actual brain shape and size (Watanabe et al., 2019). Despite 125 these limitations, endocasts still provide the best first-hand information on brain size and shape 126 in extinct species.

127

128

\section{Skull size and body mass estimation of Triceratops specimens}

To reconstruct total skull lengths for FPDM-V-9677 and 9775, we calculated the maximum cross-sectioned area for occipital condyles using their widths and heights (Anderson, 1999). Anderson (1999) demonstrated a correlation between the occipital condyle area and total skull length of Triceratops and obtained the following regression equation:

$$
\mathrm{Y}=0.464 \mathrm{X}+1.416
$$
where $\mathrm{Y}=\log$ total skull length $(\mathrm{mm})$ and $\mathrm{X}=\log$ occipital condyle area $\left(\mathrm{mm}^{2}\right)$. The occipital condyle height and width of FPDM-V-9677 are $95 \mathrm{~mm}$ and $94 \mathrm{~mm}$, respectively, resulting in the occipital condyle area of $7014 \mathrm{~mm}^{2}$. On the other hand, the occipital condyle height and width of FPDM-V-9775 are $87 \mathrm{~mm}$ and $91 \mathrm{~mm}$, respectively, resulting in the occipital condyle area of $6217 \mathrm{~mm}^{2}$. Substituting these values of the occipital condyle areas for X yields the total skull lengths of $1585 \mathrm{~mm}$ for FPDM-V-9677 and $1514 \mathrm{~mm}$ for FPDM-V-9775. These estimates must be accepted as approximations, as the fit for the regression proposed by Anderson (1999) is not statistically significant $(\mathrm{p} \sim 0.064)$, and the sample size to derive the regression equation was small $(\mathrm{n}=5)$.

The estimated total skull lengths of FPDM-V-9677 and 9775 are close to the measured total skull lengths of BSP1964 I458 (formerly YPM 1834) (Ostrom, 1986). Therefore the body mass estimate for BSP1964 I458 (4963.6 kg) by Seebacher (2001) was used as the best body mass estimate for our specimens..

147

\section{Linear measurements}

150

The maximum linear dimensions of the olfactory bulb region of FPDM-V-9677 were

151

152

153

154

155 measured to estimate the degree of relative development of the olfactory bulb for Triceratops. We followed Zelentisky, Therrien \& Kobayashi (2009) and compared their value with that of other archosaurs. Ratios of the maximal linear dimensions of the olfactory bulb against that of cerebral hemisphere (log olfactory ratio) were calculated.

To assess the degree of development of semicircular canals in Triceratops, we calculated the ratio between the height and external diameter of the ASC, and the ratio between the total height 
156

157

158

159

160

161

162

163

164

165

166

167

168

169

170

171

172

173

174

175

176

177

178

179

180

181

182

183

184

185

186

187

188

189

190

191

192

193

194

195

of the PSC and height of PSC below the plane of lateral semicircular canal (LSC) for FPDM-V9677 and 9775 . We compared them by collecting such data via a literature search on other ceratopsians (Brown, 1914; Hopson, 1979; Zhou et al., 2007; Witmer \& Ridgely, 2008), ankylosaurians (Domínguez et al., 2004), pachycephalosaurians (Domínguez et al., 2004; Bourke et al., 2014), ornithopods (Domínguez et al., 2004; Evans, Ridgely \& Witmer, 2009), sauropods (Knoll et al., 2012), and theropods (Witmer \& Ridgely, 2009; Azuma et al., 2016), and adding these values to a plot presented in Domínguez et al. (2004).

The endosseous cochlear duct length (CL) of Triceratops was obtained from FPDM-V9775. Additionally, those of other dinosaurs were measured from the figures in the literature (Witmer \& Ridgely, 2008; Evans, Ridgely \& Witmer, 2009; Witmer \& Ridgely, 2009; Leahey et al., 2015; Paulina-Carabajal, Lee \& Jacobs, 2016). The basilar papilla lengths of FPDM-V- 9775 and other dinosaurs with known CL were calculated following Gleich et al. (2005). These basilar papilla lengths were assigned to a regression equation $Y=5.7705 \mathrm{e}^{-0.25 \mathrm{X}}(\mathrm{X}=$ basilar papilla length, $\mathrm{Y}=$ best frequency of hearing) (Gleich et al. 2005) to calculate the best frequency of hearing of Triceratops. The calculated best frequency of hearing was assigned to a regression equation, $\mathrm{Y}=1.8436 \mathrm{X}+1.0426(\mathrm{X}=$ best frequency of hearing, $\mathrm{Y}=$ high frequency hearing limit), to calculate the high frequency hearing limit.

\section{Results}

The length from the rostral margin of the cerebrum to the caudal margin of the medulla of FPDM-V-9677 is $157 \mathrm{~mm}$ and its total length including the olfactory bulbs is $220 \mathrm{~mm}$. The olfactory bulbs of FPDM-V-9677 are preserved, and the olfactory tracts extend ventrally (Fig. 1). The rostral margin of the olfactory bulbs is obscured. The endocast volume including that of olfactory bulbs is $434 \mathrm{~cm}^{3}$. The volume of olfactory bulbs is $30 \mathrm{~cm}^{3}$. In the forebrain region of FPDM-V-9775, olfactory bulb, olfactory tracts, and a portion of cerebral hemispheres are missing (Fig. 2). The rostrocaudal length of FPDM-V-9775 is $136 \mathrm{~mm}$, and its total volume is $338 \mathrm{~cm}^{3}$.

The cerebral hemispheres are dorsoventrally broad in FPDM-V-9677 (Fig. 1). The cerebrum of FPDM-V-9677 appears as a rounded swelling as in that of Pachyrhinosaurus lakustai (Witmer \& Ridgely, 2008). Caudal to the cerebrum, the optic tectum is not clearly visible, and the cerebellum is indistinct from the hindbrain region in both specimens (Figs. 1 and 2). Additionally, there is no indication that the cerebellum had a floccular lobe. While the optic tectum of Triceratops has been suggested discriminable from the midbrain region (Forster 1996), Hopson (1979) was unable to identify this structure. We also were unable to observe the optic tectum in our specimens.

Vascular elements may also be distinguished in the endocasts (Figs. 1 and 2). The caudal middle cerebral veins are visible in the endocast of FPDM-V-9775, and located between the paired semicircular canals and trigeminal nerves (Fig. 2). Although the pituitary region is preserved in both specimens, its preservation in FPDM-V-9775 is only partial (Fig. 2). The 
196 pituitary region is funnel-shaped, and the carotid arteries extend from the ventral tip of this

197

198

199

200

201

202

203

204

205

206

207

208

209

210

211

212

213

214

215

216

217

218

219

220

221

222

223

224

225

226

227

228

229

230

231

232

233

234

235

region in FPDM-V-9677 (Figs. 1 and 2).

\section{Cranial nerves}

Endocasts do not represent illustrated traces of cranial nerves only and reflect the morphology of the cranial nerves and their accompanying assemblage of soft tissues, such as blood vessels. However, since it is difficult to observe cranial nerves and other soft tissues in isolation, we will focus mainly on cranial nerves here.

The olfactory system is not preserved in FPDM-V-9775, while it can be identified in FPDMV-9677 (Fig. 1). The olfactory tracts extend from the cerebral hemisphere and are relatively long. The thickness of the olfactory bulbs varies among specimens, and FPDM-V-9677 appears to be relatively thin. The olfactory bulbs of SMM P 2014.3.1C (Erickson, 2017) are much thinner and more dorsally inclined than in FPDM-V-9677 and other specimens (e.g. Bürckhardt, 1892; Marsh, 1896; Hay, 1909, Hopson, 1979; Forster, 1996). Those striking morphological differences of the olfactory bulbs may be due to a molding artifact, or that the olfactory bulbs are difficult to observe as an endocast in the archosaurs in general.

Both the right optic nerve (CN II) canal and the oculomotor nerve (CN III) canal are preserved in FPDM-V-9677 (Fig. 1). The trochlear nerve (CN IV) canal cannot be reconstructed in either of the two specimens because of the preservation.

The trigeminal nerve $(\mathrm{CN} \mathrm{V})$ is located at the rostral end of the medulla, rostrally adjacent to $\mathrm{CN}$ VII in both specimens (Figs. 1 and 2). The ophthalmic nerve $\left(\mathrm{CN} \mathrm{V}_{1}\right)$ canal extends rostrally to the middle level of the cerebrum in FPDM-V-9677, and the maxillomandibular nerve $\left(\mathrm{CN} \mathrm{V}_{2-}\right.$ 3) canal extends laterally at a right angle to the ophthalmic branch (Fig. 1). Although $\mathrm{CN} \mathrm{V}_{1}$ and $\mathrm{CN} \mathrm{V}_{2-3}$ follow the same course outward from the brain, they run separated through the braincase and, thus, appear from different foramina, as observed in other chasmosaurines such as Anchiceratops (Hopson, 1979). This is in contrast to centrosaurines like Pachyrhinosaurus, which shows the two trigeminal nerve trunks branching from the endocast in closer association (Witmer \& Ridgely, 2008; Tykoski \& Fiorillo, 2012).

The abducens nerve (CN VI) canal is preserved only in FPDM-V-9775 and passes rostroventrally from the rostroventral end of the medulla through the both sides of the pituitary (Fig. 2). The facial nerve (CN VII) canal is visible on both sides of FPDM-V-9775. The vestibulocochlear nerve (CN VIII) canal is not preserved in either of the two specimens.

The glossopharyngeal nerve (CN IX), vagus nerve (CN X), and accessory (CN XI) nerve may be linked together, extending caudolaterally from the lateral region of the medulla (Figs. 1 and 2). These nerves exit the vagal canal located posterior to the inner ear. Erickson (2017) and other previous studies (e.g. Bürckhardt, 1892; Marsh, 1896; Hay, 1909; Gilmore, 1919; Hopson, 1979; Forster, 1996) seem to have misidentified columellar canals as the canal of CN VII, VIII, or IX-XI. The hypoglossal nerve (CN XII) canal can be observed in both specimens (Figs. 1 and 2), passing caudolaterally to exit through one opening located in the exoccipital, as seen in Pachyrhinosaurus lakustai (Witmer \& Ridgely, 2008). 
236

237

238

239

240

241

242

243

244

245

246

247

248

249

250

251

252

253

254

255

256

257

258

259

260

261

262

263

264

265

266

267

268

269

270

271

272

273

274

275

\section{Endosseous labyrinth}

The labyrinths of the inner ears are preserved on both sides of the specimens under study. The left inner ear of FPDM-V-9755 is particularly well preserved (Figs. 2 and 3). The semicircular canals are located caudolaterally to the cerebellum in both FPDM-V-9677 and 9775 (Figs. 1 and 2). The ASC is round in general morphology. In particular, the arc of the ASC is relatively low dorsoventrally, differing from tall arcs of both Psittacosaurus (Zhou et al., 2007; Buller et al., 2019; Napoli et al., 2019) and Protoceratops (Hopson, 1979). The PSC is slightly lower dorsoventrally than the ASC when the LSC is oriented horizontally (Fig. 3). The LSC is the shortest in length of the three canals. The cochlear duct is preserved in FPDM-V-9775 ventral to the vestibular apparatus (Fig. 3), and its length is $17.95 \mathrm{~mm}$, longer than those of the lambeosaurine hadrosaurids (Evans, Ridgely \& Witmer, 2009) and of Pachyrhinosaurus (Witmer \& Ridgely, 2008). The ratio between the height and external diameter of the ASC (relative height of the ASC) of FPDM-V-9775 is 0.85, whereas the ratio between the height of the PSC and the height of the PSC below the plane of LSC (relative degree of ventral expansion of the PSC below the plane of LSC) is 0.29 .

\section{Discussion}

\section{Skull size and body weight}

We estimated the total skull length of both FPDM-V-9677 and FPDM-V-9775 from occipital condyle area (Anderson, 1999), resulting in roughly the same skull length between the two specimens: $159.4 \mathrm{~cm}$ and $151.1 \mathrm{~cm}$, respectively. Therefore, we assume both Triceratops specimens are of approximately the same body weight.

\section{Olfactory bulbs and sense of smell}

Olfactory bulb size has been used as an indicator of the acuity of the sense of smell in extant mammals and archosaurs, and a positive correlation has been reported between the olfactory bulb size and olfactory acuity (Cobb, 1960; Zelentisky, Therrien \& Kobayashi, 2009). We calculated the olfactory ratios of FPDM-V-9677 (Triceratops), Psittacosaurus lujiatunensis (Zhou et al., 2007), Corythosaurus sp., Hypacrosaurus altispinus (Evans, Ridgely \& Witmer, 2009), and

Stegoceras validum (Bourke et al., 2014) following Zelentisky, Therrien \& Kobayashi (2009) and compared these data in a scatter plot for relative olfactory bulb size against body mass for theropods and other archosaurs (Fig. 4; Table 1). Consequently, Triceratops is plotted considerably below the regression line, i.e., olfactory ratio to body mass of other dinosaurs, indicating that the acuity of the sense of smell of Triceratops was lower than the average of other dinosaurs and alligators (Fig. 4). On the other hand, Psittacosaurus is plotted above the regression line, indicating the sense of smell of Psittacosaurus was quite sharp among them. Our result contrasts with the observations from Psittacosaurus, a primitive ceratopsian, which had enlarged olfactory bulbs, but is concordant with the small size of the olfactory bulbs in 
276 Pachyrhinosaurus (Witmer \& Ridgely, 2008). Due to the lack of available body mass data for 277 other ceratopsians, it is impossible to calculate their olfactory ratios for quantitative analysis. 278 Nonetheless, it is hypothesized that ceratopsians reduced their sense of smell in the course of 279 evolution.

280

281

282

283

284

285

286

287

288

289

290

291

292

293

294

295

296

297

298

299

300

301

302

303

304

305

306

307

308

309

310

311

312

313

314

315

\section{Alert head posture}

The alert head posture of extinct animals can be evaluated by orienting the LSC horizontally (Duijm, 1951; Witmer et al., 2008). Although the orientation and morphology of the LSC are variable intra- and interspecifically, the LSC is useful for reconstructing head posture and locomotion of extinct animals, taking into account the degree of morphological variation and phylogeny (Duijm, 1951; Marugán-Lobón, Chiappe \& Farke, 2013; Berlin, Kirk \& Rowe, 2013; Coutier et al., 2017). In fact, the estimation of head posture using LSC has been conducted in the ceratopsian Anchiceratops (Tait \& Brown, 1928). On the other hand, a study using the Procrustes method have concluded that prediction of alert head posture by LSC is difficult since variability of LSC relative to skull landmarks of dinosaurs are large (Marugán-Lobón, Chiappe \& Farke, 2013). Therefore, estimated alert posture of the head by LSC should be accepted with caution.

By adjusting the braincase of FPDM-V-9775 in a reconstructed skull model, it was found that the beak is oriented relatively downward (Fig. 5). Thus, Triceratops likely had an alert head posture such that the basicranial axis was inclined approximately $45^{\circ}$ below the horizontal plane. At this head posture, their two horns and frill would have faced straight forward at an angle efficient for displaying, and their beak inclined slightly to the ground to facilitate grazing. Ostrom \& Wellnhofer (1928) found that when the inferior margin of the maxilla of Triceratops is horizontal, the occipital condyle projects downward by about 30 to 35 degrees, indicating that the head was carried in a "pitch forward" posture, which is supported by the alert head posture based on LSC in this study.

\section{Stabilization of gaze and posture}

Semicircular canals are related to the sense of balance, equilibrium, agility of locomotion, and stabilization of gaze (Spoor et al., 2007; Witmer et al., 2008). To assess the developmental degree of semicircular canals, Domínguez et al. (2004) calculated the ratio between the height and external diameter of the ASC and the ratio between the height of the PSC and the PSC below the plane of LSC of Archaeopteryx and compared this to that of Aves, non-archosaur reptiles and archosaurs. We calculated these ratios for Triceratops (FPDM-V-9677 and 9775) and compared them to those of other dinosaurs (Fig. 6, Table 2). Although Domínguez et al. (2004) used a large set of data for extant and extinct archosaurs, it seems not the case for non-avian dinosaurs. Therefore, we included additional data for the animals based on literature published after Domínguez et al. (2004). According to the scatter plot, Triceratops and other derived ceratopsians (Anchiceratops and Pachyrhinosaurus) are plotted in a lower area than Psittacosaurus and Protoceratops (Fig. 6), indicating that the vertical semicircular canals (ASC and PSC) of Triceratops and other derived ceratopsians are less well-developed than those of

Peer) reviewing PDF | (2020:03:46666:3:0:NEW 14 Aug 2020) 
316 primitive ceratopsians (Psittacosaurus and Protoceratops). Thus, we conclude that sensory input 317 for the reflexive stabilization of gaze and posture in Triceratops was lower than those of 318 primitive ceratopsians. The ASC is also strongly correlated with locomotor mode. It has been 319 suggested that bipedal dinosaurs exhibit well-developed ASC, while quadrupedal dinosaurs do

320

321

322

323

324

325

326

327

328

329

330

331

332

333

334

335

336

337

338

339

340

341

342

343

344

345

346

347

348

349

350

351

352

353

354

355 not (Georgi et al., 2013). Therefore, our observation that primitive, bipedal ceratopsians have better-developed ASC than derived, quadrupedal ceratopsians may reflect the difference in their locomotor modes. It should be noted that plotting ratios against ratios does not take into account the effects of allometry and may hinder information and variability in the data. However, the ASC and the ventral part of the PSC are prominent in birds, most of which exhibit exceptional three-dimensional motility among terrestrial vertebrates. Thus, the development of ASC and the ventral part of the PSC are very likely correlated with animal motility. In addition, the strong reduction of the LSC is observed in quadrupedal, less-mobile sauropods (Witmer et al., 2008) and this configuration is similar to that of Triceratops in this study. Witmer et al. (2008) suggested that mediolateral eye and head movements were less important to sauropods because their LSC is short. Similarly, Triceratops probably was not well adapted to the mediolateral head movement.

\section{Hearing ability}

In FPDM-V-9677 and 9775, the CL and basilar papilla length are longer than those of other dinosaurs analyzed in this study with exceptions of those of Pawpawsaurus and Kunbarasaurus (Fig. 7; Table 3). A basilar papilla length is defined by Gleich et al. (2005) as two-thirds of the corresponding CL. Although Evans, Ridgery \& Witmer (2009) calculated the best frequency of hearing for Lambeosaurines using the equation derived in Gleich et al. (2005), their calculation was based on the CL rather than the basilar papilla length as originally proposed by Gleich et al. (2005). Therefore, the calculated hearing frequencies in this study do not match those of Evans, Ridgery \& Witmer (2009).

Following Gleich et al. (2005), the best frequency of hearing for Triceratops is estimated $290 \mathrm{~Hz}$ based on the basilar papilla length of FPDM-V-9677 and 9775. Although the hearing ranges of multiple dinosaur taxa were calculated in this study, these are outside the range of the original data used to derive the equation in Gleich et al. (2005). Therefore, it was necessary to extrapolate the regression and the confidence interval of Gleich et al. (2005) to assess the hearing ranges of dinosaurs, accepting that the extrapolation may result in overestimation or underestimation of the true hearing ranges of the animals. Nonetheless, compared to other dinosaurs, Triceratops appears to have been adapted to hearing relatively lower frequency. As low frequencies would be less susceptible to scattering and reflection by objects in the path of the sound (Poole et al., 1988; Lewis \& Fay, 2004), Triceratops may have been sensitive to sounds from long distances.

\section{Conclusions}


356

357

358

359

360

361

362

363

364

365

366

367

368

369

370

371

372

373

374

375

376

377

378

379

380

381

382

383

384

385

386

387

388

389

390

391

392

393

394

Based on our interpretations of the endocranial anatomy of Triceratops, we suggest that (1) the sense of smell was lower than those of most, if not all, other dinosaurs; (2) the alert head posture was angled so that their frills and horns faced front against potential threads, and their beaks pointed to the ground to facilitate grazing; (3) mean hearing frequency was relatively lower among dinosaurs; and (4) lower ability to stabilize gaze inhibited rapid head movements compared to primitive ceratopsians, such as Psittacosaurus and Protoceratops.

\section{Acknowledgements}

We thank the staffs at Nikon Instech's High-Resolution X-ray CT Facility for access and assistance to conduct CT analyses, and the researchers and staffs of Fukui Prefectural Dinosaur Museum for providing information about the specimens. The members of the Institute of Dinosaur Research, Fukui Prefectural University provided helpful comments and suggestions for this study. This manuscript was greatly improved by comments from Brandon Hedrick (Louisiana State University Health Sciences Center), Andrew Farke (Raymond M. Alf Museum of Paleontology), Jason Bourke (New York Institute of Technology College of Osteopathic Medicine) and an anonymous reviewer. The authors would also like to thank Enago (www.enago.jp) for the English language review.

\section{References}

Anderson JS. 1999. Occipital condyle in the ceratopsian dinosaur Triceratops, with comments on body size variation. Contributions from the Museum of Paleontology, University of Michigan 30:215-231.

Azuma Y, Xu X, Shibata M, Kawabe S, Miyata K, Imai T. 2016. A bizarre theropod from the Early Cretaceous of Japan highlighting mosaic evolution among coelurosaurians. Scientific Reports 6:20478. DOI: 10.1038/srep20478.

Berlin JC, Kirk EC, Rowe TB. 2013. Functional Implications of Ubiquitous Semicircular Canal Non-Orthogonality in Mammals. PloS One 8:e79585

Bullar CM, Zhao Q, Benton MJ, Ryan MJ. 2019. Ontogenetic braincase development in Psittacosaurus lujiatunensis (Dinosauria: Ceratopsia) using micro-computed tomography. PeerJ 7: e7217 DOI: 10.7717/peerj.7217.

Bürckhardt R. 1892. Das Gehirne von Triceratops flabellatus Marsh. Neues Jahrbuch für Mineralogie, Geologie and Paläontologie 1892 (Bd.2): 71-72. [in German]. 
395

396

397

398

399

400

401

402

403

404

405

406

407

408

409

410

411

412

413

414

415

416

417

418

419

420

421

422

423

424

425

426

427

428

429

430

431

432

433

434

Brown DB. 1914. Anchiceratops, a new genus of horned dinosaurs from the Edmonton Cretaceous of Alberta; with Discussion of the origin of the ceratopsian crest and the brain casts of Anchiceratops and Trachodon. Bulletin of the American Museum of Natural History 33: 539-548.

Brown DB, Schlaikjer DEM. 1940. The structure and relationships of Protoceratops. Transactions of the New York Academy of Sciences 2: 99-100.

Bourke JM, Porter WR, Ridgely RC, Lyson TR, Schachner ER, Bell PR, Witmer LM. 2014. Breathing life into dinosaurs: tackling challenges of soft-tissue restoration and nasal airflow in extinct species. The Anatomical Record 297: 2148-2186. DOI: 10.1002/ar.23046.

Cobb S. 1960. A Note on the Size of the Avian Olfactory Bulb. Epilepsia 1 (1-5): 394-402. DOI: 10.1111/j.1528-1157.1959.tb04276.x.

Corfield JR, Wild JM, Cowan BR, Parsons S, Kubke MF. 2008. MRI of postmortem specimens of endangered species for comparative brain anatomy. Nature Protocols 3 (4): 597-605. DOI: $10.1038 /$ nprot.2008.17.

Coutier F, Hautier L, Cornette R, Amson E, Billet G. 2017. Orientation of the lateral semicircular canal in Xenarthra and its links with head posture and phylogeny. Journal of Morphology 278 (5): 704-717

Domínguez Alonzo P, Milner AC, Ketcham RA, Cookson MJ, Rowe TB. 2004. The avian nature of the brain and inner ear of Archaeopteryx. Nature 430: 666-669. DOI: 10.1038 /nature02706.

Duijm M. 1951. On the head posture of some birds and its relation to some anatomical features. Proceedings of the Koninklijke Nederlandse Akademie van Wetenschappen 54: 260-271.

Erickson BR. 2017. HISTORY OF THE CERATOPSIAN DINOSAUR TRICERATOPS in the Science Museum of Minnesota; 1960-Present. Science Museum of Minnesota Monograph 12: Paleontology.

Evans DC, Ridgely R, Witmer LM. 2009. Endocranial anatomy of lambeosaurine hadrosaurids (Dinosauria: Ornithischia): A sensorineural perspective on cranial crest function. The Anatomical Record 292:1315-1337. DOI: 10.1002/ar.20984.

Forster CA. 1996. New information on the skull of Triceratops. Journal of Vertebrate Paleontology 16: 246-258. DOI: 10.1080/02724634.1996.10011312. 
435

436

437

438

439

440

441

442

443

444

445

446

447

448

449

450

451

452

453

454

455

456

457

458

459

460

461

462

463

464

465

466

467

468

469

470

471

472

473

474

Georgi JA, Sipla JS, Forster CA. 2013. Turning semicircular canal function on its head:

$$
\text { dinosaurs and a novel vestibular analysis. PLOS ONE 8:e58517. doi: }
$$

10.1371/journal.pone.0058517.

Gilmore CW. 1919. A new restoration of Triceratops, with notes on the osteology of the genus. Proceedings of the United States National Museum 55: 97-112.

Gleich O, Dooling RJ, Manley G. 2005. Audiogram, body mass, and basilar papilla length: correlations in birds and predictions for extinct archosaurs. Naturwissenschaften 92: 595598.

Hay OP. 1909. On the skull and the brain of Triceratops with notes on the brain-cases of Iguanodon and Megalosaurus. Proceedings of the United States National Museum 36: 95108

Hopson JA. 1979. Paleoneurology. In: Grans C, Northcutt RG, Ulinski P, eds. London academic Press 9: 39-146.

Jerison HJ. 1973. Evolution of the brain and intelligence. New York: Academic Press.

Knoll F, Witmer LM, Ortega F, Ridgely RC, Schwarz-Wings D. 2012. The braincase of the basal sauropod dinosaur Spinophorosaurus and 3D reconstructions of the cranial endocast and inner ear. PLoS ONE 7: e30060 DOI: 10.1371/journal.pone.0030060.

Langston Jr. W. 1975. The Ceratopsian Dinosaurs and Associated Lower Vertebrates from the St. Mary River Formation (Maastrichtian) at Scabby Butte, Southern Alberta. Canadian Journal of Earth Sciences 12: 1576-1608.

Leahey LG, Molnar RE, Carpenter K, Witmer LM, Salisbury SW. 2015. Cranial osteology of the ankylosaurian dinosaur formerly known as Minmi sp. (Ornithischia: Thyreophora) from the Lower Cretaceous Allaru Mudstone of Richmond, Queensland, Australia. PeerJ 3: e1475 DOI: $10.7717 /$ peerj. 1475 .

Lewis ER, Fay RR. 2004. Environmental Variables and the Fundamental Nature of Hearing. In: Manley GA, Popper AN, Fay RR, eds. Evolution of the vertebrate auditory system. New York: Springer, 27-54.

Marsh OC. 1896. The dinosaurs of North America. Annual Report of the United States Geological Survey 16: 133-244.

Peer] reviewing PDF | (2020:03:46666:3:0:NEW 14 Aug 2020) 
475 Marugán-Lobón J, Chiappe LM, Farke AA. 2013. The variability of inner ear orientation in 476 saurischian dinosaurs: testing the use of semicircular canals as a reference system for 477 comparative anatomy. PeerJ 1(9):e124

478

479

480

481

482

483

484

485

486

487

488

489

490

491

492

493

494

495

496

497

498

499

500

501

502

503

504

505

506

507

508

509

510

511

512

513

514

Napoli JG, Hunt T, Erickson GM, Norell MA. 2019. Psittacosaurus amitabha, a New Species of Ceratopsian Dinosaur from the Ondai Sayr Locality, Central Mongolia. American Museum Novitates 3932: 1-36.

Ostrom J, Wellnhofer P. 1986. The Munich Specimen of Triceratops with a Revision of the Genus. Zitteliana 14: 111-158.

Paulina-Carabajal A, Lee YN, Jacobs LL. 2016. Endocranial morphology of the primitive nodosaurid dinosaur Pawpawsaurus campbelli from the Early Cretaceous of North America. PLoS ONE 11(3): e0150845. 1-22. DOI: 10.1371/journal.pone.0150845.

Poole JH, Payne K, Langbauer WR, Moss CJ. 1988. The social contexts of some very low frequency calls of African elephants. Behavioral Ecology and Sociobiology 22: 385-392.

Seebacher F. 2001. A new method to calculate allometric length-mass relationships of dinosaurs. Journal of Vertebrate Paleontology 21: 51-60.

Spoor F, Bajpai S, Hussain ST, Kumar K, Thewissen JGM. 2002. Vestibular evidence for the evolution of aquatic behaviour in early cetaceans. Nature 417: 163-166.

Spoor F, Garland T, Krovitz G, Ryan TM, Silcox MT, Walker A. 2007. The primate semicircular canal system and locomotion. Proceedings of the National Academy of Sciences of the United States of America 104: 10808-10812. DOI: 10.1073/pnas.0704250104.

Spoor F, Zonneveld F. 1998. Comparative review of the human bony labyrinth. American Journal of Physical Anthropology 107: 211-251.

Tait J, Brown B. 1928. How the Ceratopsia carried and used their head. Transactions of the Royal Society of Canada, Series 3, 22:13-23

Turkewitsch BG. 1934. Zur Anatomie des Gehörorgans der Vögel (Canales semicirculares). Zeitschrift für Anatomie und Entwicklungsgeschichte 103: 551-608. DOI: 10.1007/BF02118934.

Tykoski RS, Fiorillo AR. 2013. Beauty or brains? The braincase of Pachyrhinosaurus perotorum and its utility for species-level distinction in the centrosaurine ceratopsid Pachyrhinosaurus.

Peer] reviewing PDF | (2020:03:46666:3:0:NEW 14 Aug 2020) 
515

516

517

518

519

520

521

522

523

524

525

526

527

528

529

530

531

532

533

534

535

536

537

538

539

540

541

542

543

544

545

546

Earth and Environmental Science Transactions of the Royal Society of Edinburgh 103: 487499. DOI: $10.1017 / \mathrm{S} 1755691013000297$.

Watanabe A, Gignac PM, Balanoff AM, Green TL, Kley NJ, Norell MA. 2019. Are endocasts good proxies for brain size and shape in archosaurs throughout ontogeny? Journal of Anatomy 234: 291-305. DOI: 10.1111/joa.12918.

Witmer LM, Ridgely RC, Dufeau DL, Semones MC. 2008. Using CT to peer into the past: 3D visualization of the brain and ear regions of birds, crocodiles, and nonavian dinosaurs. In: Endo H, Frey R, eds. Anatomical imaging: Towards a new morphology. Tokyo: Springer Verlag, 67-88

Witmer LM, Ridgely RC. 2009. New insights into the brain, braincase, and ear region of Tyrannosaurs (Dinosauria, Theropoda), with implications for sensory organization and behavior. The Anatomical Record 292: 1266-1296. DOI: 10.1002/ar.20983.

Witmer, LM., Ridgely RC. 2008. Structure of the brain cavity and inner ear of the centrosaurine ceratopsid dinosaur Pachyrhinosaurus based on CT scanning and 3D visualization. In: Currie PJ, Langstone W Jr, Tanke DH, eds. A New Horned Dinosaur from an Upper Cretaceous Bone Bed in Alberta. Ottawa: National Research Council of Canada, 117-144.

Zelentisky DK, Therrien F, Kobayashi Y. 2009. Olfactory acuity in theropods: Palaeobiological and evolutionary implications. Proceedings of the Royal Society of London B: Biological Sciences 276: 667-673. DOI: 10.1098/rspb.2008.1075.

Zhang QN, King JL, Li DQ, Hou YM, You HL. 2019. Endocranial morphology of Auroraceratops sp. (Dinosauria: Ceratopsia) from the Early Cretaceous of Gansu Province, China. Historical Biology. DOI: 10.1080/08912963.2019.1588893

Zhou CF, Gao KQ, Fox RC, Du XK. 2007. Endocranial morphology of psittacosaurs (Dinosauria: Ceratopsia) based on CT scans of new fossils from the Lower Cretaceous, China. Palaeoworld 16: 285-293. DOI: 10.1016/j.palwor.2007.07.002. 


\section{Figure 1}

Cranial endocast (A-C) and braincase (D-F) of FPDM-V-9677.

(A, D) left lateral, (B, E) ventral, and (C, F) dorsal views. Brain endocast represented by pink coloring; cranial nerves by yellow; carotid artery by red; venous canals by blue; endosseous labyrinth by purple. Abbreviations: car, cerebral carotid artery canal; c, cochlea; cc, columellar canal; cbl, cerebellum; cer, cerebral hemisphere; cvcm, caudal middle cerebral vein; lab, labyrinth; ob, olfactory bulb; otc, olfactory tract; II, optic nerve canal; III, oculomotor nerve canal; IV, trochlear nerve canal; $\mathrm{V}_{1}$, ophthalmic nerve canal; $\mathrm{V}_{2-3}$, maxillomandibular nerve canal; VI, abducens nerve canal; VII, facial nerve canal; IX-XI, shared canal for glossopharyngeal, vagus, and accessory nerves; XII, hypoglossal nerve canal; bop, basioccipital process; cap, capitate process of laterosphenoid; oc, occipital condyle; pop, paroccipital process. 
A

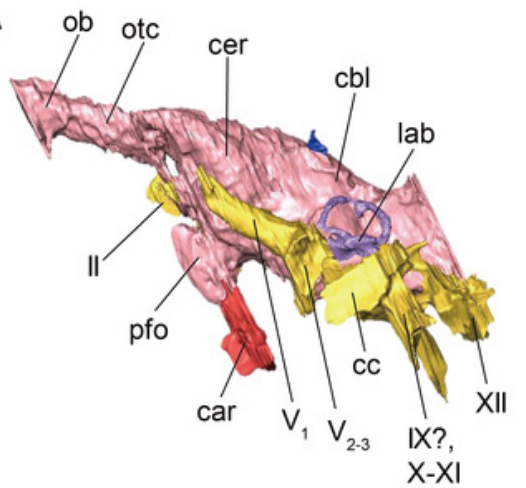

D

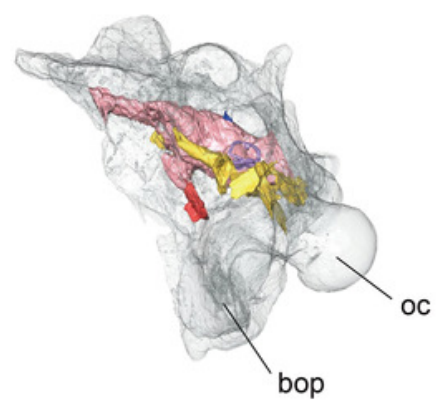

B

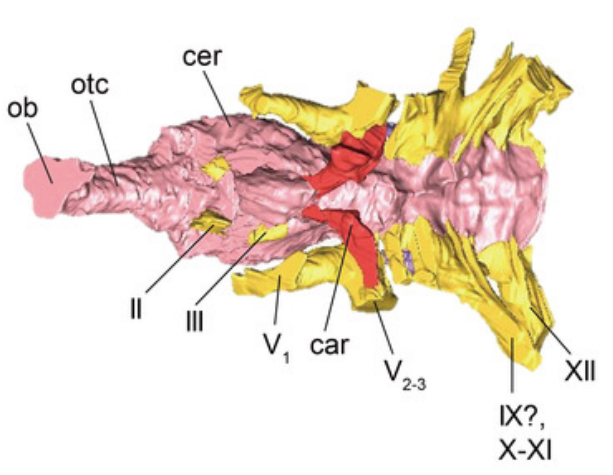

$10 \mathrm{~cm}$

E

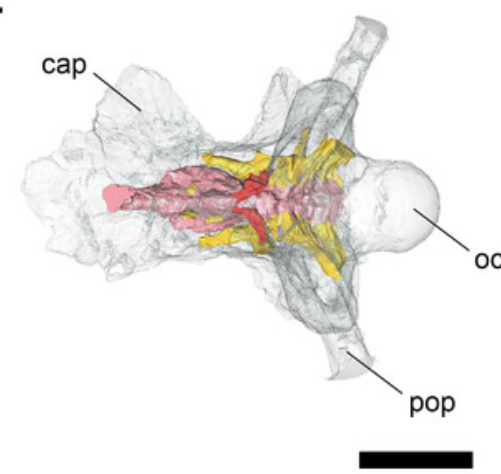

$10 \mathrm{~cm}$
C

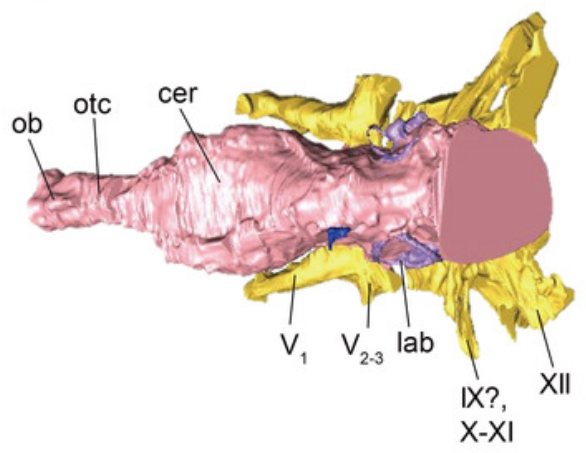

F

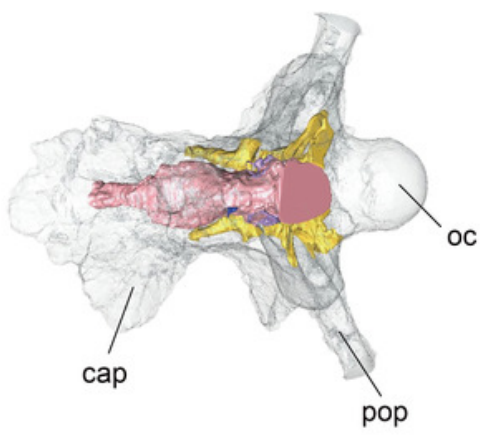


Figure 2

Cranial endocast (A-C) and braincase (D-F) of FPDM-V-9775.

$(A, D)$ left lateral, (B, E) ventral, and (C, F) dorsal views. Color scheme and abbreviations are given in the caption of Fig. 1.

A

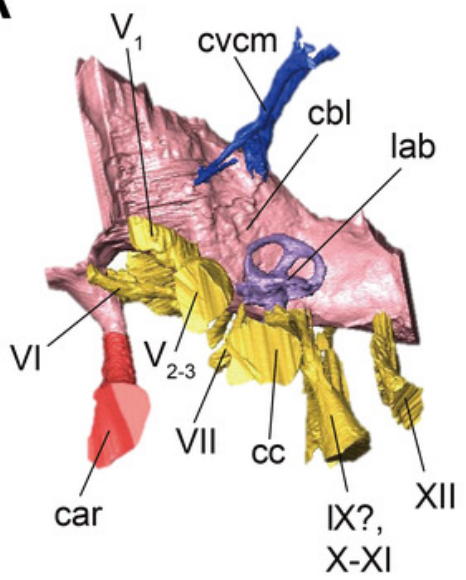

D

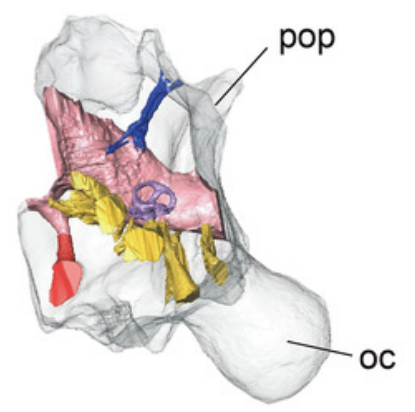

B

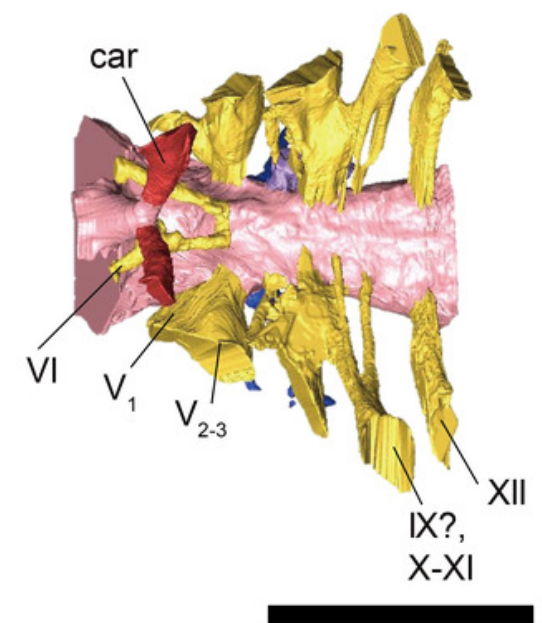

$10 \mathrm{~cm}$

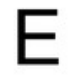

E

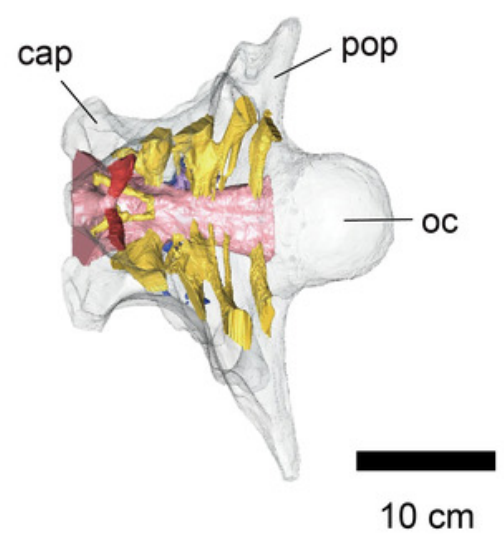

C

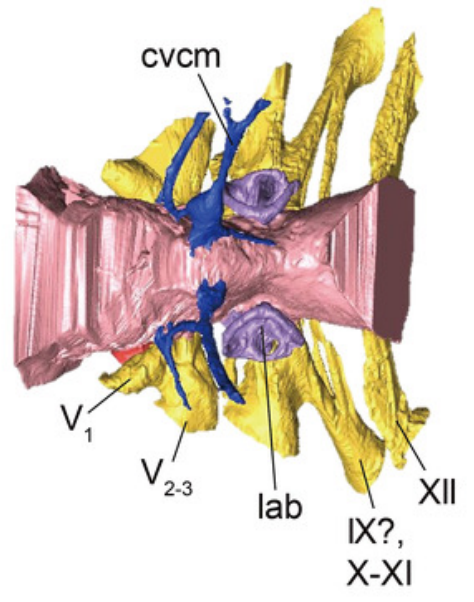

$\mathrm{F}$

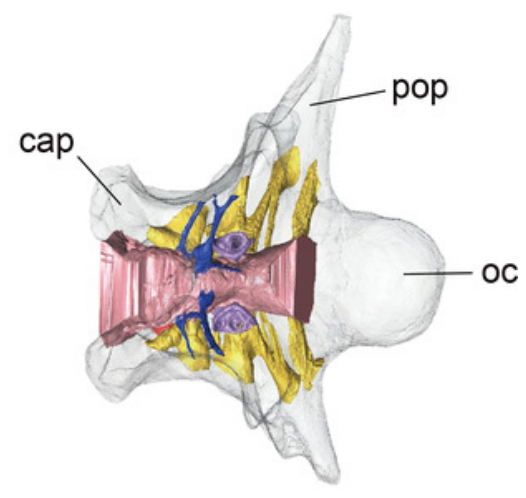




\section{Figure 3}

Left $(A-C)$ and right (D-H) endosseous labyrinth of FPDM-V-9775, and left (G-H) endosseous labyrinth of FPDM-V-9677

$(A, D, G)$ lateral, $(B, E, H)$ posterior, and $(C, F, I)$ dorsal views. Abbreviations: $A S C$, anterior semicircular canal; C, cochlea; CRC, crus commune; LSC, lateral semicircular canal; PSC, posterior semicircular canal; VE, vestibule of inner ear. 


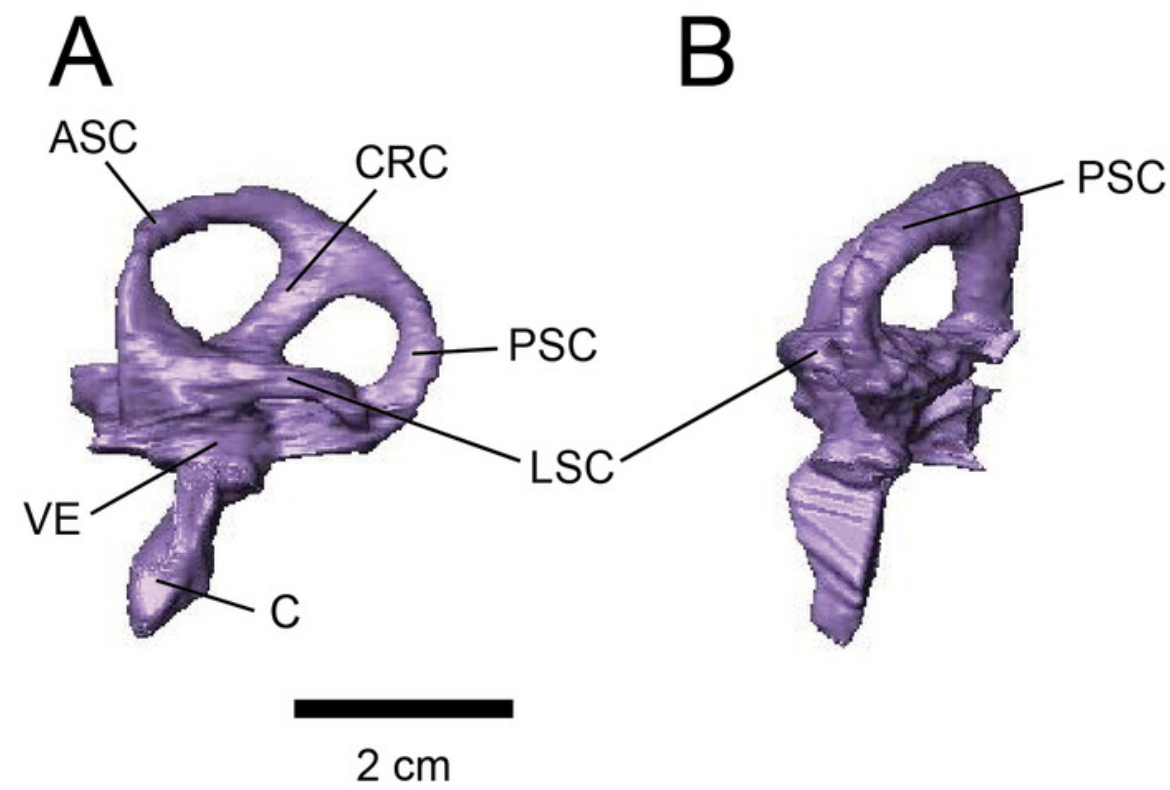

C
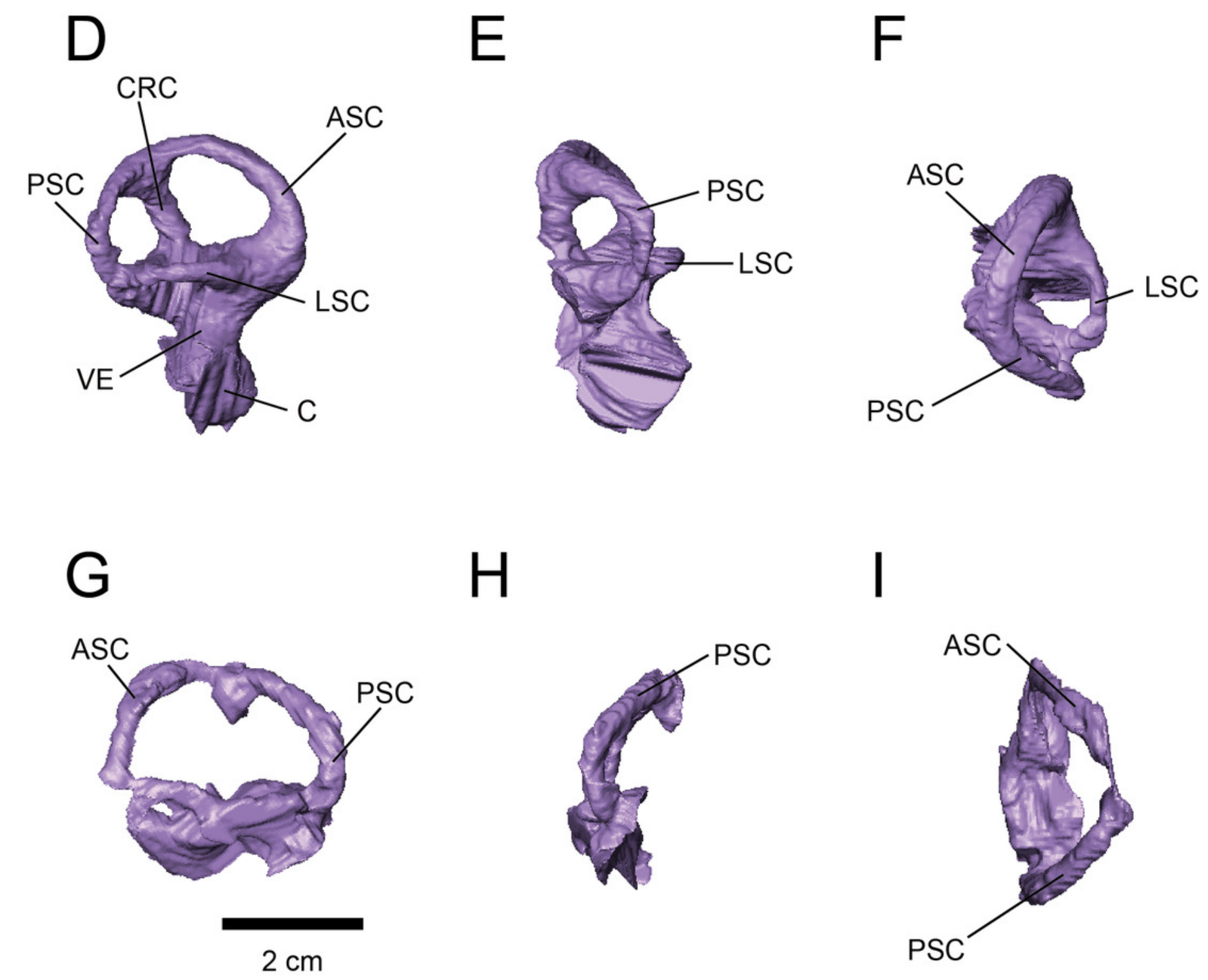


\section{Figure 4}

Relationship between olfactory ratio and body mass for selected dinosaurs.

Gray circles indicate data for theropods, gray triangles for crocodilians, and the regression line shows that the relationship between olfactory ratio and body mass in theropods. These data are from Zelentisky, Therrien \& Kobayashi (2009). In our study, we added data for Triceratops, Corythosaurus, Hypacrosaurus and Stegoceras to their data.

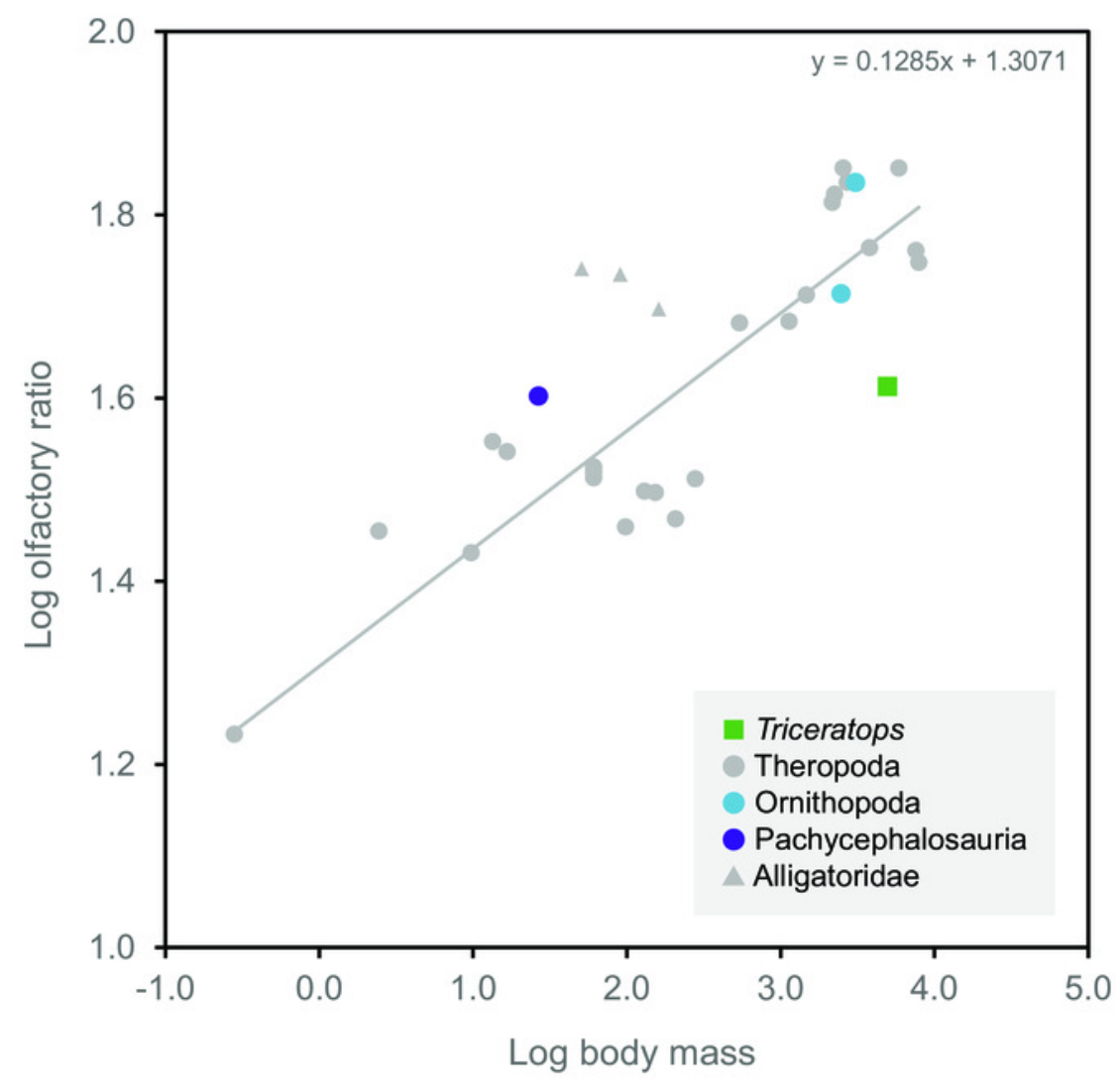


Figure 5

Alert head posture of Triceratops based on orienting the skull such that the lateral semicircular canal is horizontal.

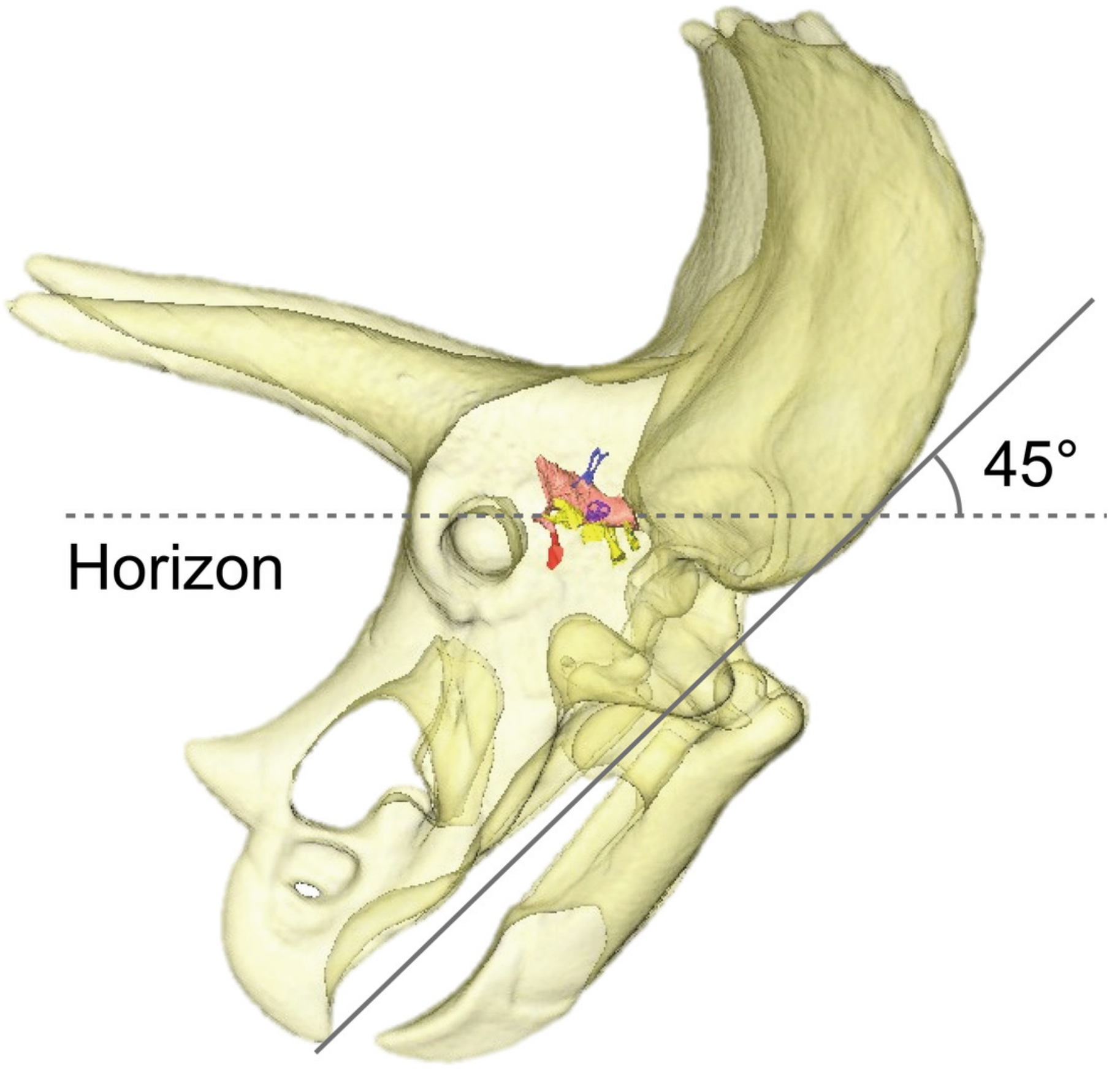


Figure 6

Comparative proportions of the endosseous labyrinth of ceratopsians, selected recent birds, archosaurs and non-archosaur reptiles.

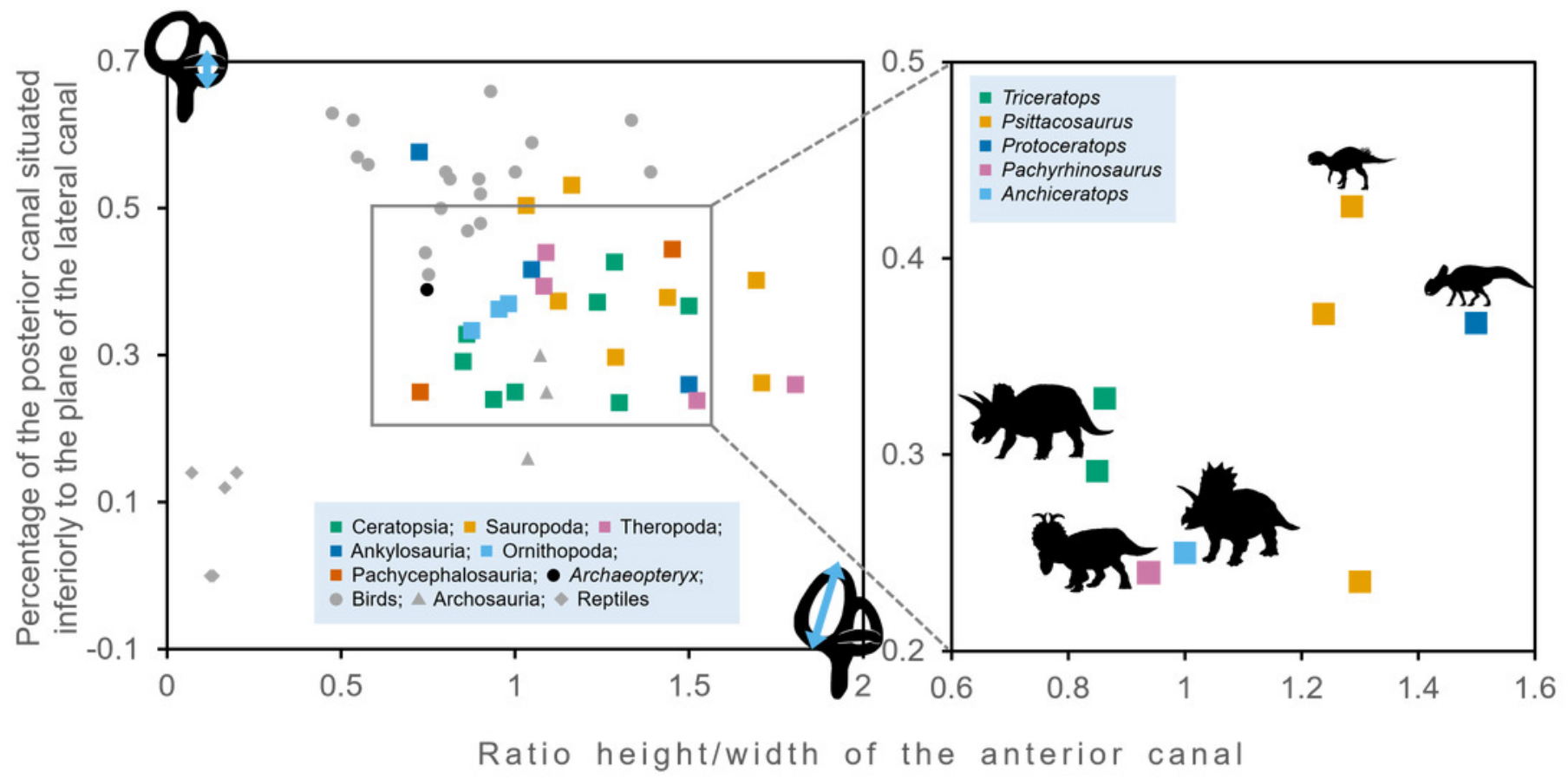




\section{Figure 7}

Best frequency of hearing and high frequency hearing limit for selected dinosaurs calculated from the regression of Gleich et al. (2005).

Blue color shows best frequency of hearing $(\mathrm{Hz})$, and orange color shows high frequency hearing limit $(\mathrm{Hz})$.

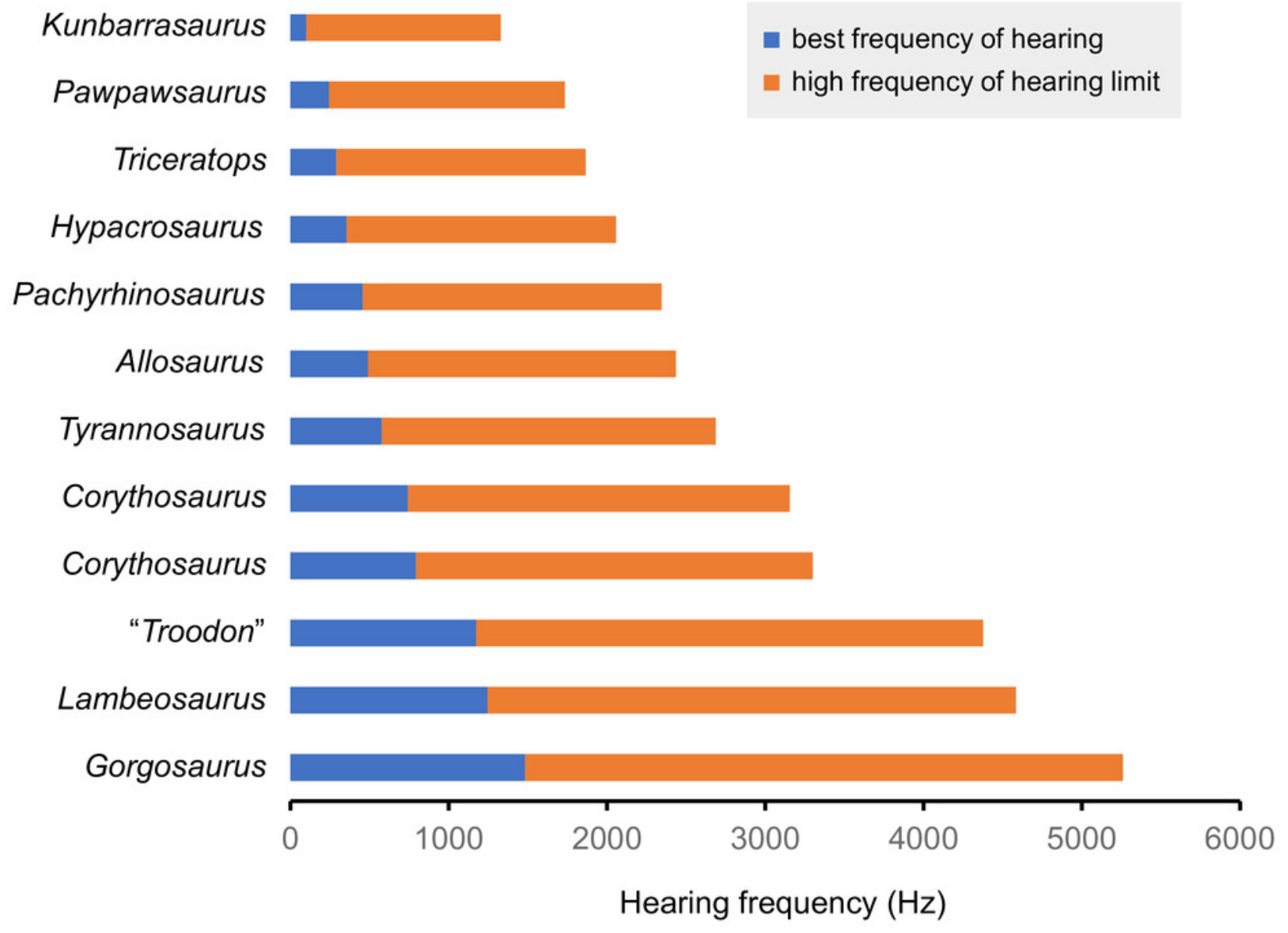




\section{Table 1 (on next page)}

Olfactory ratios and body masses of Triceratops, Corythosaurus, Hypacrosaurus and Stegoceras.

Olfactory ratios calculated following the method of Zelenitsky, Therrien \& Kobayashi (2009). 


\begin{tabular}{|c|c|c|c|c|c|c|c|}
\hline Species & $\begin{array}{c}\text { Specimen } \\
\text { details }\end{array}$ & $\begin{array}{c}\text { Olfactory } \\
\text { ratio (\%) }\end{array}$ & $\begin{array}{c}\text { Log } \\
\text { olfactory } \\
\text { ratio }\end{array}$ & $\begin{array}{c}\text { Body } \\
\text { mass (kg) }\end{array}$ & $\begin{array}{c}\text { Log body } \\
\text { mass }\end{array}$ & $\begin{array}{c}\text { References } \\
\text { (brain } \\
\text { endocast) }\end{array}$ & $\begin{array}{c}\text { References } \\
\text { (body mass) }\end{array}$ \\
\hline $\begin{array}{c}\text { Triceratops sp. } \\
9677\end{array}$ & $\begin{array}{c}\text { FPDM-V- } \\
\text { sp. }\end{array}$ & CMN 34825 & 68.42 & 1.835 & 3078.5 & 3.488 & $\begin{array}{c}\text { Seebacker, } \\
2001\end{array}$ \\
\hline $\begin{array}{c}\text { Corythosaurus } \\
\text { Rypacrosaurus } \\
\text { altispinus }\end{array}$ & ROM 702 & 51.72 & 1.714 & 2478.0 & 3.394 & $\begin{array}{c}\text { Evans, } \\
\text { Ridmer, 2009 }\end{array}$ & $\begin{array}{c}\text { Evans, } \\
\text { Ridgely \& } \& \\
\text { Witmer, 2009 }\end{array}$ \\
\hline $\begin{array}{c}\text { Stegoceras } \\
\text { validum }\end{array}$ & UALVP 2 & 40.00 & 1.602 & 26.7 & 1.427 & $\begin{array}{c}\text { Evans, } \\
\text { Ridgely \& } \\
\text { Witmer, 2009 } 2009\end{array}$ \\
\hline
\end{tabular}

1 


\section{Table 2 (on next page)}

Proportions of the inner ear of Triceratops and selected dinosaurs.

"Relative anterior canal height" shows height of the anterior canal/external diameter of anterior canal. "Relative posterior canal height" shows height from the base of the posterior canal to the plane of the lateral canal/height of the posterior canal. 


\begin{tabular}{|c|c|c|c|c|}
\hline Species & Specimen details & $\begin{array}{c}\text { Relative } \\
\text { anterior canal } \\
\text { height }\end{array}$ & $\begin{array}{c}\text { Relative } \\
\text { posterior } \\
\text { canal height }\end{array}$ & References \\
\hline Triceratops sp. & FPDM-V-9677 & 0.863 & 0.328 & - \\
\hline Triceratops sp. & FPDM-V-9775 & 0.85 & 0.292 & - \\
\hline $\begin{array}{c}\text { Psittacosaurus } \\
\text { lujiatunensis }\end{array}$ & IVPP V15451 & 1.286 & 0.426 & Bullar et al., 2019 \\
\hline $\begin{array}{c}\text { Psittacosaurus } \\
\text { lujiatunensis }\end{array}$ & IVPP V12617 & 1.237 & 0.371 & Bullar et al., 2019 \\
\hline $\begin{array}{c}\text { Psittacosaurus } \\
\text { lujiatunensis }\end{array}$ & PKUP V1054 & 1.300 & 0.235 & Zhou et al., 2007 \\
\hline Protoceratops grangeri & AMNH 6466 & 1.500 & 0.367 & Hopson, 1979 \\
\hline Pachyrhinosaurus lakustai & TMP 1989.55.1243 & 0.938 & 0.24 & $\begin{array}{c}\text { Witmer \& Ridgery, } \\
2008\end{array}$ \\
\hline Anchiceratops ornatus & AMNH 5259 & 1 & 0.25 & Brown, 1914 \\
\hline Hypacrosaurus altispinus & ROM 702 & 0.876 & 0.334 & $\begin{array}{c}\text { Evans, Ridgely \& } \\
\text { Witmer, } 2009\end{array}$ \\
\hline Corythosaurus sp. & CMN 34825 & 0.954 & 0.363 & $\begin{array}{c}\text { Evans, Ridgely \& } \\
\text { Witmer, } 2009\end{array}$ \\
\hline Iguanodon bernissartensis & BMNH R 2501 & 0.981 & 0.37 & $\begin{array}{c}\text { Domínguez et al., } \\
2004\end{array}$ \\
\hline Euoplocephalus tutus & AMNH 5337 & 1.5 & 0.26 & Leahey et al., 2015 \\
\hline Kunbarrasaurus ieversi & QM F18101 & 0.724 & 0.577 & Leahey et al., 2015 \\
\hline Pawpawsaurus campbelli & FWMSH93B.00026 & 1.048 & 0.417 & $\begin{array}{c}\text { Paulina-Carabajal, } \\
\text { Lee \& Jacobs, } \\
2016\end{array}$ \\
\hline $\begin{array}{c}\text { Pachycephalosaurus } \\
\text { grangeri }\end{array}$ & AMNH 1696 & 0.727 & 0.25 & $\begin{array}{c}\text { Domínguez et al., } \\
2004\end{array}$ \\
\hline Stegoceras validum & UALVP 2 & 1.452 & 0.444 & Bourke et al., 2014 \\
\hline $\begin{array}{c}\text { Massospondylus } \\
\text { carinatus }\end{array}$ & $\mathrm{BP} / 1 / 4779$ & 1.289 & 0.297 & Knoll et al., 2012 \\
\hline $\begin{array}{c}\text { Spinophorosaurus } \\
\text { nigerensis }\end{array}$ & GCP-CV-4229 & 1.709 & 0.262 & Knoll et al., 2012 \\
\hline Nigersaurus taqueti & MNN GAD512 & 1.163 & 0.532 & Knoll et al., 2012 \\
\hline Diplodocus longus & CM 3452 & 1.693 & 0.402 & Knoll et al., 2012 \\
\hline
\end{tabular}




\begin{tabular}{|c|c|c|c|c|}
\hline Camarasaurus lentus & CM 11338 & 1.125 & 0.374 & Knoll et al., 2012 \\
\hline Giraffatitan brancai & MB.R.2180.22.1-4 & 1.439 & 0.379 & Knoll et al., 2012 \\
\hline Jainosaurus septentrionalis & ISI R162 & 1.032 & 0.504 & Knoll et al., 2012 \\
\hline Tyrannosaurus rex & AMNH FR 5117 & 1.083 & 0.394 & $\begin{array}{c}\text { Witmer \& Ridgely, } \\
2009\end{array}$ \\
\hline Gorgosaurus libratus & ROM 1247 & 1.523 & 0.239 & $\begin{array}{c}\text { Witmer \& Ridgely, } \\
2009\end{array}$ \\
\hline Allosaurus fragilis & UMNH VP 18050 & 1.804 & 0.260 & $\begin{array}{c}\text { Witmer \& Ridgely, } \\
2009\end{array}$ \\
\hline Fukuivenator paradoxus & FPDM-V8461 & 1.089 & 0.44 & Azuma et al., 2016 \\
\hline
\end{tabular}




\section{Table 3 (on next page)}

Values of cochlear lengths (CL), and calculated basilar papilla length, best frequency of hearing and high frequency hearing limit.

"Basilar papilla length", "Best frequency of hearing" and "High frequency hearing limit" were calculated following the method of Gleich et al. (2005). 


\begin{tabular}{|c|c|c|c|c|c|c|}
\hline Species & $\begin{array}{l}\text { Specimen } \\
\text { details }\end{array}$ & $\begin{array}{c}\mathrm{CL} \\
(\mathrm{mm})\end{array}$ & $\begin{array}{l}\text { basilar papilla } \\
\text { length (mm) }\end{array}$ & $\begin{array}{c}\text { Best } \\
\text { frequency } \\
\text { of hearing } \\
(\mathrm{Hz})\end{array}$ & $\begin{array}{l}\text { High } \\
\text { frequency } \\
\text { of hearing } \\
\text { limit }(\mathrm{Hz})\end{array}$ & references \\
\hline Triceratops sp. & $\begin{array}{l}\text { FPDM-V- } \\
9775\end{array}$ & 17.95 & 12.0 & 0.290 & 1.577 & - \\
\hline $\begin{array}{c}\text { Pachyrhinosau } \\
\text { rus lakustai }\end{array}$ & $\begin{array}{c}\text { TMP } \\
1989.55 .1243\end{array}$ & 15.2 & 10.1 & 0.458 & 1.887 & $\begin{array}{c}\text { Witmer \& } \\
\text { Ridgely, } 2008\end{array}$ \\
\hline $\begin{array}{c}\text { Tyrannosaurus } \\
\text { rex }\end{array}$ & $\begin{array}{c}\text { AMNH FR } \\
5117\end{array}$ & 13.8 & 9.2 & 0.579 & 2.109 & $\begin{array}{c}\text { Witmer \& } \\
\text { Ridgely, } 2009\end{array}$ \\
\hline $\begin{array}{c}\text { Gorgosaurus } \\
\text { libratus }\end{array}$ & ROM 1247 & 8.15 & 5.4 & 1.484 & 3.778 & $\begin{array}{c}\text { Witmer \& } \\
\text { Ridgely, } 2009\end{array}$ \\
\hline $\begin{array}{c}\text { Allosaurus } \\
\text { fragilis }\end{array}$ & $\begin{array}{c}\text { UMNH VP } \\
18050\end{array}$ & 14.8 & 9.9 & 0.490 & 1.945 & $\begin{array}{c}\text { Witmer \& } \\
\text { Ridgely, } 2009\end{array}$ \\
\hline $\begin{array}{l}\text { "Troodon } \\
\text { formosus" }\end{array}$ & $\begin{array}{c}\text { composite of } \\
\text { TMP } \\
86.36 .457 \\
\text { and TMP } \\
79.8 .1\end{array}$ & 9.56 & 6.4 & 1.173 & 3.205 & $\begin{array}{c}\text { Witmer \& } \\
\text { Ridgely, } 2009\end{array}$ \\
\hline $\begin{array}{c}\text { Hypacrosaurus } \\
\text { altispinus }\end{array}$ & ROM 702 & 16.7 & 11.1 & 0.357 & 1.700 & $\begin{array}{l}\text { Evans, Ridgely } \\
\text { \& Witmer, } 2009\end{array}$ \\
\hline $\begin{array}{c}\text { Lambeosaurus } \\
\text { sp. }\end{array}$ & ROM 758 & 9.2 & 6.1 & 1.245 & 3.339 & $\begin{array}{l}\text { Evans, Ridgely } \\
\& \text { Witmer, } 2009\end{array}$ \\
\hline $\begin{array}{c}\text { Corythosaurus } \\
\text { sp. }\end{array}$ & ROM 759 & 11.9 & 7.9 & 0.794 & 2.507 & $\begin{array}{l}\text { Evans, Ridgely } \\
\text { \& Witmer, } 2009\end{array}$ \\
\hline $\begin{array}{c}\text { Corythosaurus } \\
\text { sp. }\end{array}$ & CMN 34825 & 12.3 & 8.2 & 0.743 & 2.412 & $\begin{array}{l}\text { Evans, Ridgely } \\
\text { \& Witmer, } 2009\end{array}$ \\
\hline $\begin{array}{c}\text { Kunbarrasauru } \\
\text { s ieversi }\end{array}$ & QM F18101 & 24.3 & 16.2 & 0.101 & 1.228 & $\begin{array}{l}\text { Leahey et al., } \\
2015\end{array}$ \\
\hline $\begin{array}{c}\text { Pawpawsaurus } \\
\text { campbelli }\end{array}$ & $\begin{array}{c}\text { FWMSH93B. } \\
00026\end{array}$ & 19 & 12.7 & 0.243 & 1.491 & $\begin{array}{c}\text { Paulina- } \\
\text { Carabajal et al., } \\
2016\end{array}$ \\
\hline
\end{tabular}

